Attila Krizsán

University of Turku, Finland

\title{
SCHOLA EUROPAEA: SCHOOLING EUROPEANS? - A PRELIMINARY RESEARCH REPORT ${ }^{1}$
}

\begin{abstract}
This study explores the creation of identities and values and the social production of citizens in a Type II Schola Europaea institution. My analysis focuses on pupils' patterns of identification and their system of values as are represented in their language use. In this analysis special attention is paid to students' expressions of their relationship to the EU (European identity creation) and the values connected to the creation of social and political identities of the pupils. The linguistic investigation is performed by corpus-driven systemic-functional analysis of Transitivity processes and Appraisal. Based on Halliday's system of transitivity ${ }^{2}$ and Martin \& White's appraisal theory ${ }^{3}$ the corpus-driven systemic-functional analytic approach is proven to be a highly effective instrument in exposing patterns of identification, values and self-positioning ${ }^{4}$.

Existing only for a few years, Type II Schola Europaea institutions are the latest development in the "Europeanization" of public education and they represent a new object of study. To date, no research has been conducted in this area from the perspective of applied linguistics, nor has any study focused on the "outcomes" produced by Schola Europaea institutions, such as the ways pupils in these schools express their social and political identities in their communication. Thus, the relevance of this research is that it provides new empirical information about the politics of identity construction, the dissemination of values and the potential of these unique institutions to create "European citizens".
\end{abstract}

1 The author would like to thank the Network for European Studies of the University of Helsinki for the initial funding of the research project.

2 M.A.K. Halliday, C.M.I.M. Matthiessen, An Introduction to Functional Grammar, London 2004.

3 J.R. Martin, P.R.R. White, The Language of Evaluation, Appraisal in English, London-New York 2005.

4 Cf. A. Krizsán, 'The EU is not Them, but Us!' - The First Person Plural and the Articulation of Collective Identities in European Political Discourse, Newcastle 2011. 